\author{
Wiktoria Bilawska, \\ doktor nauk humanistycznych w zakresie literaturoznawstwa \\ Katedry Literatury Powszechnej i Dydaktyki \\ Żytomierskiego Uniwersytetu Państwowego imienia Iwana Franki \\ ORCID: 0000-0001-5676-3945 \\ wiktoria11288@gmail.com \\ Olga Rudiuk, \\ doktor nauk humanistycznych w zakresie literaturoznawstwa \\ Katedry Literatury Powszechnej i Dydaktyki \\ Żytomierskiego Uniwersytetu Państwowego imienia Iwana Franki \\ ORCID: 0000-0003-0375-3596 \\ olunkabuz7@gmail.com
}

\title{
GATUNEK DZIENNIKA WE WSPOMNIENIACH Z PODRÓŻY DO SYBERII, POBYTU W BEREZOWIE I W SARATOWIE EWY FELIŃSKIEJ
}

$W$ artykule na podstawie Wspomnień z podróży do Syberii, pobytu $w$ Berezowie $i w$ Saratowie E. Felińskiej zostały przeanalizowane charakterystyczne cechy gatunkowe dziennika, jego modyfikacji gatynkowych, w tym dziennika syberyjskiego, dziennika z przymusowej podróży, dziennika domowego. Uwaga byta skupiona także na liście osobistym, który autorka umieściła w tekście dziennika bez naruszania jego struktury.

Wyrazy kluczowe: E. Felińska, gatunek, list, modyfikacja gatunkowa, dziennik, wspomnienia.

\section{Вікторія Білявська, Ольга Рудюк. Жанр щчоденника в «Спогадах з подорожі до Сибіру,} перебування в Березові та Саратові» Сви Фелінськоӥ

У статті на прикладі «Спогадів з подорожі до Сибіру, перебування в Березові та Саратові» Сви Фелінської проаналізовано характерні генологічні риси щзоденника, а також його жанрові модифікаиії, серед яких сибірський щзоденник, щуоденник примусової подорожі, домашній щзоденник. Звернено увагу на особистий лист, який авторка вміло вплела в текст без порушення його логічної структури.

Ключові слова: $С$. Фелінська, жанр, лист, жанрова модифікація, щоденник, спогади.

Viktoriya Bilavska, Olha Rudiuk. Diary Genre in Eva Felinska's "Memories of the Journey to Siberia, Staying in Berezove and Saratov"

"Memories of the Journey to Siberia, Staying in Berezove and Saratov" by Eva Felinska is a complex genre-style formation of memoir literature of the Right Bank of Ukraine in the Romantic era with characteristic features of positivist tendencies. It is united by a common thematic idea, recording and contemplating on the events which took place during the author's forced journey to Siberia and stay in places of exile. Assimilation at the level of subgenres and modifications as a result of further "shaking" of the genealogical paradigm of the Enlightenment under the influence of the formation of a new individual romantic authorial consciousness, inherent in the literature of the first half of the nineteenth century, acquired a new stylistic color and functionality. Within the general subgenre dominance of women's Siberian memories of exile, a travel diary, forced travel,

private letters, folk tales, article, review, business economic document were combined, which

together made E. Felinska's "Memories of the Journey to Siberia..." interesting for a wider audience of readers, making it possible to present various spheres of socio-historical development of the era and directly construct and present a multifaceted image of the memoirist, which has not disappeared against the large-scale background of the era. E. Felinska's diary style is characterized by certain conciseness, attention is focused on the most significant events, and in the center of the image there is a nomination, the text provides above all cognitive-scientific informativeness. With the continuation of work on "Memories of the Journey to Siberia..." genre modification of the Siberian diary of forced travel, getting rid of the features of exotic space and 
Wiktoria Bilawska, Olga Rudiuk. Gatunek dziennika we Wspomnieniach z podróży do Syberii, pobytu w Berezowie $i$ w Saratowie Ewy Felińskiej

ethnographic color, inherent in depicting the customs and traditions of indigenous peoples of the North, turns into a household diary that covers the everyday realities of the life of the writer-exile.

Keywords: E. Felinska, genre, letter, genre modification, diary, memories.

Wprowadzenie. Aresztowanie, skazanie i zesłanie E. Felińskiej na Syberię w 1839 r. pozostało historycznym precedensem, kiedy po raz pierwszy w historii Imperium Rosyjskiego Polkaszlachcianka została skazana na dożywotnie zesłanie z całkowitą konfiskatą majątku za działalność polityczną - członkostwo i współpracę z konspiracyjnym Stowarzyszeniem Ludu Polskiego Szymona Konarskiego. Podczas pobytu na Syberii aktywnie zajmowała się badaniem północnego folkloru i etnografii, historii i kultury egzotycznej przestrzeni. Dziedzictwem jej działalności kulturalnej było powstanie słynnego utworu - Wspomnień z podróży do Syberii, pobytu $w$ Berezowie $i$ w Saratowie. Dzieło złożone, eklektyczne, które pod wieloma względami odpowiada wymaganiom czasu, a pod wieloma względami go wyprzedza.

Z korespondencji E. Felińskiej do J. I. Kraszewskiego wiadomo, że autorka pracę nad Wspomnień z podróży do Syberii... zaczęła w 1845 roku, czyli po powrocie do ojczyzny. Aby nadać opisywanym zdarzeniom charakter naturalistycznego szkicu i jednoczesność żywych scen, pamiętnikarka zastosowała metodę skracania dystansu czasowego, przenosząc przeszłość w teraźniejszość, jakby pisała swój dziennik na Syberii, tam i teraz, lecz nie cztery lata później. Można powiedzieć kilka faktów o pewnych mistyfikacjach związanych z czasem artystycznym tekstu.

Po pierwsze, E. Felińska daje wiele informacji paraliterackich, w tym znaczną ilość informacji geograficznych, w tym topograficznych, np. usytuowanie niektórych obiektów z dokładnymi współrzędnymi geograficznymi ich położenia, czy przedstawianie przestrzeni syberyjskiej z lotu ptaka. Np. autorka pisze: «Jekaterynburg leży nad Isetem. Jasny dowód, że się przebyło grzbiet Uralów, i że się znajduje na wschodniej pochyłości tego gór łańcucha, to, że wody wypływające z gór, zaczynają należeć do innego systemu. Dotąd, rzeki biorące początek w górach Uralskich spływały na zachód, i tam, jedne biorąc kierunek na południe, wlewały swe wody do morza Kaspijskiego, drugie zwracając się na północ, tonęły w oceanie lodowatym. Teraz przeciwnie, wody płyną na wschód, dążąc wszystkie do olbrzymiej Oby, która przyjmując dań z południa, zachodu i wschodu, rozramienia swe wody i przynosi je do odnogi, której nadaje swe nazwisko. Jekaterynburg, chociaż założony niedawno, bo dopiero w 1723 r., jest miastem pięknie zabudowanym i ludnym; tu jest główny zarząd górnictwa, i mennica państwa. Prócz tego, to miasto posiada wiele fabryk kruszcowych i szlifiernię kamieni. W Jekaterynburgu, za bardzo mierną cenę można dostać kosztownych kamieni. Ametysty, opale, chalcedony, chryzolity, górne kryształy, topazy, akwamaryny, szmaragdy i mnóstwo innych, to oszlifowane, to do oprawy, to lekko oprawne, nastręczają się do kupienia. Jak zgłodniały Arab, co znalazłszy wór pereł na pustyni, potrącił nogą z pogardą i powiedział: «tylko perły». równie i ja spojrzałam z obojętnością, i pojechałam dalej» [2, s. 29], ale dokładny opis systemu rzecznego w okolicach Jekaterynburga lub różne nazwy kamienia szlachetnego nie pozwala uwierzyć, że mamy do czynienia ze spontaniczną refleksją człowieka, który skończył naukę domową w wieku 11 lat i był «geograficznym samoukiem».

Po drugie, istnieje pewna różnica stylistyczna pomiędzy narracją Wspomnień z podróży do Syberii... a osobistymi listami do dzieci E. Felińskiej, w którym ona opowiada o Berezowie i ogranicza się informacją o pogodzie i ostatnich wydarzeniach w mieście. Szczery styl listów i pamiętników, a także chęć naukowego opisania i przekazania pożytecznych doświadczeń przetrwania, zdobytych podczas pobytu w przestrzeni syberyjskiej.

Stosowanie takich podejść można uznać za sposób na zwiększenie obiektywizmu, co pozwala na rozumienie świata przedstawionego w kategorii rzeczywistości, w ramach wiedzy empirycznej autora, co powinno zwiększyć zaufanie do tekstu z pozycji odbiorcy. Wizja Syberii przedstawiona na stronach Wspomnień z podróży do Syberii... zniszczyła infernalny mit tej przestrzeni, który był 
wcielony w świadomość narodową poprzez literatów polskich, którzy jednak nigdy nie byli w roli zesłańców.

Materiały i metody. Dla różnych modyfikacji gatunkowych, które powstały w systemie literatury wspomnieniowej na pograniczu ukraińsko-polskim w połowie XIX w. w wyniku przeobrażeń stałego systemu hierarchii gatunków Oświecenia pod wpływem nowych nurtów zarówno romantyzmu, jak i pozytywizmu, był charakterystyczny proces «migracji» genologicznej na poziomie międzygatunkowym. Dzieła pamiętnikowe E. Felińskiej jako organiczny składnik procesów rozpowszechnionych w przestrzeni europejskiej oraz w literaturze Prawobrzeża Ukrainy na początku i w połowie XIX w. także odzwierciedliły nowe tendencje estetyczne owych czasów. W granicach jednego tekstu wspomnień autorki można znaleźć organiczne wspólnie funkcjonujące gatunki, w tym dziennik, podróż, list, a także bajka, artykuły publicystyczne, etnograficzne, geograficzne, recenzje itp. Gatunkowe elementy dziennika i listu wielokrotnie odnajdujemy we Wspomnieniach z podróży do Syberii, pobytu w Berezowie $i$ w Saratowie. Gatunek podróży, posiadający różnorodne środki stylistyczne i środki organizowania przestrzeni artystycznej $\mathrm{W}$ tekstach wspomnieniowych, jest charakterystyczny i dla Wspomnień z podróży do Syberii i dla Pamiętników z życia E. Felińskiej.

Piechota M. w Słowniku literatury polskiej XIX wieku podaje, że w potocznej świadomości pierwszej połowy XIX w. dziennik nie od razu wiązano z szeroko rozumianą literaturą. L. B. Linde na w obrębie tego hasła podawał znaczenie: «rejestr albo księgi, w które się wpisuje każdego dnia sprawy $<\ldots>>$ lub gatunek pism periodycznych. Prawie do połowy XIX w. słowo «dziennik» obrasta w nowe znaczenia, wśród nich na pierwszym miejscu «kajet do zapisywania codziennego tego, o czym się chce pamiętać, diariusz, notatnik, pamiętnik» [7, s. 202]. Formułą popularną w literaturze romantycznej były od początku dzienniki podróży. Wiązało się to nie tylko z faktem popularności dzieł w rodzaju H. Fieldinga Dziennik podróży do Lizbony czy L. Sterne'a Podróży sentymentalnej przez Francję $i$ Włochy oraz ich rodzimych i obcych naśladowań na użytek własny oraz publiczny, np. I. Czartoryjskiej Dyliżansem przez Śląsk. Dziennik podróży do Cieplic w roku 1816 czy F. S. Dmuchowskiego Włochy. Obraz historyczny $i$ opisowy krajów na półwyspie włoskim znajdujacych się oraz Sycylii, Malty, Korsyki i Sardynii (1837 r.). Wykształciła się podówczas moda obyczajowo-literacka spisywania wrażeń $\mathrm{z}$ wojaży, przy czym zazwyczaj materiał obserwacyjny dominował nad inwencją literacką autora. Była to moda i zarazem pełna pomoc wychowawcza: dziennik miał być ćwiczeniem, pomocą w samodoskonaleniu się i kształtowaniu zmysłu obserwacji, refleksji, poprawnego wnioskowania u młodego człowieka. Wiek XIX pozostawił po sobie zapisy dzienników o nader zróżnicowanej wartości: cenne, zawierające źródłowe materiały i oryginalne przemyślenia i takie, które swój walor zawdzięczają głownie otarciu autora o jakąś wielkość epoki. Jednak na plan pierwszy wysuwają się dzienniki pisarzy, literatów i ludzi z tymi kręgami najbliżej związanych [7, s. 204].

Ideą genologiczną dziennika jest przechowywanie prywatnej informacji autora. Czas między wydarzeniem a jego pierwszą refleksją w dzienniku, w porównaniu ze wspomnieniami, jest zwykle minimalny. Dziennik we wspomnieniach w przeciwieństwie do dziennika jako gatunku literatury pięknej, który pojawił się w połowie XIX w., charakteryzuje się brakiem kompletności akcji oraz doskonałej całości, co może przełamać narrację na «otwartej nucie», czyli pozostawić ją bez dalszego rozwoju lub logiczne rozwiązanie. Poetycką cechą dziennika jest to, że czas akcji rozgrywa się tu i teraz [1, s. 105]. Wiadomo, że E. Felińska, tworząc teksty zarówno wspomnień, jak i pamiętników, sięgnęła po metodę skracania dystansu czasowego. Modyfikacja gatunkowa dziennika syberyjskiego, którego przestrzeń artystyczna obejmuje wymiar terytorialny w. Berezów guberni tobolskiej w Imperium Rosyjskim, nazwana przez autorkę Dziennik spisany w Berezowie. On charakteryzuje się asymilacją odmiennej struktury i treści dominant gatunkowych. We wspomnieniach narrator dokonuje na przemian dwu operacji na swojej świadomości: przyjmuje świadomość ja piszącego z perspektywy teraźniejszości, bogatszą o doświadczenia dystansu czasowego, jaki upłynął, kiedy indziej zaś wciela się w świadomość bohatera: siebie z różnych etapów przeszłości. O ile pamiętniki w wąskim znaczeniu spisywane są z jakiegoś dystansu, 
krótszego lub dłuższego, co znajduje wyraz w przyjęciu pewnego punktu oglądu rzeczywistości odtwarzanej, o tyle inny gatunek, przynależny do rodziny genologicznej, której patronuje pamiętnik - typowy dziennik - nie operuje dystansem narratorskim. Autora dziennika nie dzieli bowiem od przedstawionej rzeczywistości dystans czasowy $<\ldots>$ spisuje on swoje dzieje na bieżąco, z dnia na dzień, co najwyżej z dystansu kilku dni [6, s. 26-27]. Formuła modelowanego dziennika wyklucza więc istotną dla pamiętnika wzajemną grę pomiędzy teraźniejszością i przeszłością, rekonstruowanie i interpretację przeszłości z perspektywy teraźniejszości, co dla E. Felińskiej pozostało środkiem pewnej stylizacji.

W granicach Dziennika spisanego w Berezowie współistnieją datowane wydarzenia, notatki z życia codziennego zesłanki, materiały dotyczące zwyczajów i tradycji Rosjan oraz ludności rdzennej. Związana $\mathrm{z}$ paradygmatem genologicznym literatury romantyzmu kontaminacja gatunkowa pozwoliła autorce na umieszczenie w tekście literackim bez naruszania jego struktury Wyjątek z listu Paulinki [2, s. 135-137], posiadające cechy charakterystyczne dla stylu epistolarnego.

Według S. Sierotwińskiego list to «wypowiedź pisemna skierowana do osoby (lub grupy osób) zwykle nieobecnej, w celu praktycznym» [9, s. 167]. Tekst listu jest samodzielnym komunikatem, strukturą zamkniętą i skonwencjonalizowaną. Teoretycznie obowiązywały w romantyzmie klasyczne schematy, według których należało komponować tekst listowy. Forma listu, użyte zwroty i formuły uzależnione są od tego, do koga dany list jest adresowany, dla kogo jest przeznaczony i w jakim celu napisany. Zróżnicowania te pociągają za sobą zmiany w strukturze tekstu.

Według wzorów retorycznych list realizuje schemat kompozycyjny, który składa się z następujących elementów: salutatio - pozdrowienie, captatio benevolentiae - pozyskanie przychylności, narratio - właściwy tekst listu, conclusio - zakończenie i petitio - podpis [10, s. 211].

Wyjątek z listu Paulinki [1, s. 135-137] umieszczony na stronach Wspomnień z podróży do Syberii... ma cechy pewnej fragmentaryczności, więc jest pozbawiony części salutatio i captatio benevolentiae. Najprawdopodobniej autorka, która miała dobre wykształcenie, świadomie podjęła tę decyzję, gdyż w dobie romantyzmu były to znane i akceptowane formy tradycyjne. Tekst listu matki do córki zaczyna się od razu od części narracyjnej, która pozwala pamiętnikarce zachować wysoki ton emocjonalny na stosunkowo równym poziomie. Obecność maksymalnego poziomu ekspresji była charakterystyczną cechą sztuki pisania listów epoki romantyzmu. Plastyczność opisu uległa silnej indywidualizacji, która miała na celu nie reprodukcję, lecz przeżycie całej gamy emocji odbiorcy. D. Grzesiak uważa, że «W romantycznej epistolografii, będącej wytworem prywatnego, indywidualnego nadawcy, nie istnieją żadne ograniczenia w wykorzystaniu tworzywa treściowego <...> . Niektóre $\mathrm{z}$ cech listu zbliżają ten gatunek wypowiedzi do innych gatunków literackich: dziennika, pamiętnika, autobiografii. W listach twórców XIX w. odnajdujemy cechy charakterystyczne dla wymienionych gatunków: obecność narratora pierwszoosobowego, pewien dystans czasowy do opowiadanych zdarzeń oraz obecność świata przedmiotowego i podmiotowego [5, s. 24-25], na podstawie czego można wytłumaczyć przyczyny umieszczenia listu w tekście Wspomnień z podróży do Syberii... bez naruszania konstrukcji i ogólnego brzmienia wspomnień.

Ton listu prywatnego, którego głównym motywem jest tęsknota dziecka za matką, nadaje tekstu pamiętnikarskiemu głębokiej intymności, nadającej czytelnikowi roli osoby, która potrafi współczuć. Taka manifestacja intymności nazywana jest sensu stricto - uczuciami, wrażeniami lub wydarzeniami, które nie są przeznaczone dla szerokiego grona czytelników, ale skierowane są tylko do wąskiego kręgu bliskich. Pamiętnikarka celowo narusza intymność listu swojej córki, umieszczając go $\mathrm{w}$ tekście Wspomnień z podróży do Syberii..., co powinno mieć na celu zwiększenie zaufania czytelników do tekstu.

Rutyna zesłania nie jest głównym tematem korespondencji i rzadko pojawia się tylko na wyraźną prośbę adresata (listy córki Wiktorii). Epistolarne dziedzictwo rodziny Felińskich z tamtego okresu nie ma cech męczeństwa, a jedynie fascynację odmiennością kulturową egzotycznych przestrzeni. 
Oprócz gatunku listu prywatnego dziennik zawiera fragmenty, mające cechy epistolarne, które funkcjonują bez tytułu, arbitralnie wplecione w tekst pamiętnika i wykorzystywane przez E. Felińską głównie w celach informacyjnych, ilustracyjnych lub potwierdzających pewne fakty. Podobne zjawisko kontaminacji podgatunku widzimy u K. Sienkiewicza w Dzienniku podróży po Anglii 1820 - 1821 [8], gdzie notatki i listy są połączone. Ze względu na to, że pamiętnikarka napisała Wspomnień z podróży do Syberii... z dość długiej perspektywy czasowej, na szczególną uwagę zasługują elementy tekstowe, które zostały wprowadzone do tekstu $\mathrm{w}$ celu ozdobienia $\mathrm{i}$ zwiększenia zainteresowania czytelnika, w tym bajki ludowe, humorystyczne historyjki oraz aforyzmy wplecione $\mathrm{w}$ strukturę narracyjną.

Po następnym przeniesieniu pamiętnikarki w $1841 \mathrm{r}$. z Berezowa do Saratowa modyfikacja dziennika syberyjskiego przewiduje zmianę definicji terytorialnej, która dla autora istnieje jako kontynuacja notacji realiów syberyjskich, choć ona wspomina, że: «Wydając niniejszą część Wspomnień, mam na celu zaznajomienie naszych ziomków $z$ pewną częścią narodu pobratymczego, którego znamy wiele członków pojedynczych, wszakże znamy po za domem, w stroju, że się tak w y rażę, podróżnym, ale życia ich domowego, wyobrażeń miejscowych wcale nie znamy. A zatem, myślę, że chociaż okolica nadwołżańska w którą przejechałam, opuszczając brzegi Soswy, nie nosi tak wydatnego piętna obcej cywilizacji jak Berezów, przecież jest zajmującą nie pod jednym względem, a dla wielu z nas równie mało znana jak strona Zauralska» [3, s. 7].

Zmiana miejsca pobytu E. Felińskiej nie wpływa na kompozycję Wspomnień z podróży do Syberii... Takie zjawisko sugeruje, po pierwsze, że modyfikację dziennika syberyjskiego należy rozumieć nie w kategoriach dominacji przestrzennej, lecz jako przynależność autora, czyli dziennik zesłańca. Fakt, że E. Felińska przeniosła się do Saratowa, nie zmienia jej pozycji jako więźnia, więc dziennik syberyjski powstaje nadal. Po drugie, pamiętnikarka celowo podjęła taki krok, aby zainteresować czytelnika, ponieważ «dziennik syberyjski» brzmi o wiele egzotyczniej i niecodziennie niż, np. «dziennik saratowski». W kompozycji przemieszczenie terytorialne jest zaznaczone tylko w datowaniu, omonim Berezów zmienia się Saratowem.

Warunki pobytu E. Felińskiej na zesłaniu w Saratowie wpłynęły na organizację masywu tekstowego drugiego i trzeciego tomu Wspomnień z podróży do Syberii... Oprócz «podróży» (bo dla E. Felińskiej było to nie podróż w zwykłym znaczeniu, lecz przemieszczenie zesłanki z jednego punktu pobytu do innego), sposobem uporządkowania tekstu i podzielenia go na oddzielne części jest datowanie z uwzględnieniem dni i lat. Wprawdzie akceptujemy autorską definicję «podróży», ale formalne wskaźniki pozwalają mówić o dzienniku podróży, a wymuszone przemieszczenie $\mathrm{w}$ przestrzeni wykazuje oznaki przymusu, co generalnie definiuje modyfikację gatunku jako «dziennik przymusowej podróży».

Kryterium terytorialne nie wpływa na definicję gatunku, ponieważ E. Felińska nadal przemieszcza się w obcej - wrogiej przestrzeni, niezależnie czy jest to Syberia, czy inne regiony Imperium Rosyjskiego. Pod względem czasu spędzonego w Saratowie ten okres obejmuje dwa i pół roku, od 1841 r. do połowy 1844 r., a syberyjski dziennik przymusowej podróży nabiera cech statyczności i zmienia charakter narracji. Odpowiada to poetyce gatunku, która przejawiała się w dwóch tendencjach: jako chronologiczna notacja wydarzeń oraz notacja podczas ruchu w przestrzeni, będąca rodzajem hybrydy genologicznej podróży i dziennika.

Spokojne życie pamiętnikarki w nadwołżańskim mieście znalazło odzwierciedlenie w wyważonej narracji zawartej w dzienniku E. Felińskiej, napisanym w Saratowie. Wśród jego cech charakterystycznych jest względna statyczność, opis szeregu takich samych dni, monotonia w wyrazie emocjonalnym, brak śladów egzotycznej przestrzeni syberyjskiej, które pozwalają mówić o powstaniu modyfikacji dziennika domowego. Ciche radości zesłanki zmieniają uczucie samotności oraz strachu, fragment datowany 28 sierpnia $1841 \mathrm{r}$.: «Rozgościłam się już trochę w Saratowie. Kontenta jestem z mego domku. Mam ciszę, porządek, czystość. I kościół tuż pod bokiem. Każdego dnia słyszę jak dzwon wzywa na mszę, i każdego dnia słuchać jej mogę; ani deszcz, ani błoto przeszkodzić nie mogą, bodom tuż koło kościoła i droga trotuarem. Przy tym sąsiedztwo i bliskie i miłe. Przez ulicę tylko mieszkanie ks. Szczytta, o trzy domy mieszkanie Chaborskich. Trochę dalej, 
bo na innej ulicy Falkowski, a staruszek Serednicki codziennym jest gościem Chaborskich. Jednolatki, z jednej ziemi, dotrzymują sobie zawsze towarzystwa, czy to pogadać o przeszłości, czy w preferansa pograć, staruszkowie zawsze razem. Nie trzeba mi więcej towarzystwa, nie mam ochoty go szukać. Oderwane ogniwo od łańcucha towarzyskiego, musiałabym być wszędzie nadpotrzebnym jego członkiem. Miejsce dla mnie właściwe tylko tu w domu. Tu nie zawadzam nikomu, nie psuję powszechnej harmonii» [4, s. 123].

W trzecim tomie Wspomnień z podróży do Syberii... opis przeżyć emocjonalnych związanych ze śmiercią córki Pauliny jest chyba jedynym otwartym i szczerym wyrazem uczuć autorki. Powściągliwość emocjonalna, zawsze uważana za przejaw dobrego wychowania, tkwiąca we Wspomnień z podróży do Syberii..., pozbawia dziennik E. Felińskiej z tego okresu oznak prywatności i osobowości. W większym stopniu dziennik poświęcony jest osobliwościom życia przedstawicieli wyższych sfer, zarówno polskiej, jak i rosyjskiej społeczności mieszkającej w Saratowie. Nowością $\mathrm{w}$ wątkach wspomnień $\mathrm{z}$ tego okresu są wrażenia autora $\mathrm{z}$ wizyt w najbogatszych i najbardziej wpływowych rodzinach Saratowa, m.in. Stołypina, Fadejewa itp., Opisy wnętrz i różnych form spędzania wolnego czasu, gry, karnawały, teatry amatorskie i nie tylko. Narracja ma cechy pewnej dygresji. Pamiętnikarka zawsze odwraca uwagę od głównego tematu, ale nie ukrywa, że ma taką cechę: «Nic obejrzałam się, że zacząwszy mówić o jarmarku, poświęciłam kart kilka szczegółom które do niego wcale nie należą. Cóż robić z tą niesforną naturą myśli mojej, która nigdy nie chce się pilnować drogi wytkniętej, ale tam leci gdzie wiatr skrzydło wykręci?» [4, s. 180]. E. Felińska twierdzi, że «wyliczone tu narodowości nie stanowią elementu tutejszego jarmarku, ledwie służą za drobne kamyki do wymozaikowania tła obrazu. Jego cechę i właściwą fizjonomję stanowią owoce przemysłu ludzi, a nie ludzie sami. Człowiek tak mały, że się nuży patrząc na dzieła Wielkiego Robotnika. Oko jego nie może objąć wielkich rozmiarów, myśl pochwycić układów cudownych sprężyn utrzymujących wieczny ruch i wieczną piękność: odwraca zatem od nich oczy zmordowane, a woli je zastanowić na łokciu atłasu, lub kawałku perskiej tkaniny, którą tym więcej podziwia im więcej kosztowała mozołu Pignejczykowi, co ją podołał uklecić» [4, s. 180]. Podobna cecha dygresyjna organizacji tekstu pozwala mówić o potrzebie pisarki kreować ogólny obraz, a nie tylko o jego poszczególne elementy, co jest charakterystyczne dla metody E. Felińskiej.

Wyniki. Styl dziennika E. Felińskiej charakteryzuje się pewną zwięzłością, uwaga skupiona jest na najważniejszych wydarzeniach, a w centrum obrazu znajduje się nominacja, tekst zapewnia przede wszystkim informatywność poznawczo-naukową. Wraz z kontynuacją prac nad Wspomnieniami $z$ podróży do Syberii... modyfikacja gatunkowa syberyjskiego dziennika przymusowej podróży, pozbawiając się cech przestrzeni egzotycznej oraz kolorytu etnograficznego, przekształca się w dziennik domowy, który obejmuje codzienne realia życia zesłanki, ostatnim fragmentem którego jest wyjazd: «Wkrótce dzwonki pocztowe zatętniały - ostateczne hasło wyjazdu. Na to hasło nastąpiły pożegnania - uściśnienia szczere, rzewne - a wśród życzeń i błogosławieństw usiadłyśmy do powozu. Jeszcze żegnamy przyjaciół ostatnim spojrzeniem, ale konie ruszyły: zagrzmiały koła powozu - i zniknęły twarze przyjaciół. Jeszcze ulice, jeszcze domy znajome, ale chwilka, a już i Saratów zniknął z przed oczu. Tylko gościniec długi, szeroki, prosty, ginie w perspektywie, a step rozległy, jednakowy, bezgraniczny morduje oko. Głos dzwonka, jedyny towarzysz, zaczął śpiewać znajomą piosnkę, i już jesteśmy w drodze» [4, s. 304].

\section{Список використаних джерел та літератури}

1. Сршов В. Польська мемуаристична література Правобережної України доби романтизму. Житомир : Полісся, 2010. 454 с.

2. Felińska E. Wspomnienia z podróży do Syberii, pobytu w Berezowie i w Saratowie. Wilno : Nakładem i drukiem J. Zawadzkiego, 1852. T. 1. $348 \mathrm{~s}$.

3. Felińska E. Wspomnienia z podróży do Syberii, pobytu w Berezowie i w Saratowie. Wilno : Nakładem i drukiem J. Zawadzkiego, 1852. T. 2. 299 s. 
4. Felińska E. Wspomnienia z podróży do Syberii, pobytu w Berezowie i w Saratowie. Wilno : Nakładem i drukiem J. Zawadzkiego, 1853. T. 3. $304 \mathrm{~s}$.

5. Grzesiak D. Struktura listu romantycznego (na przykładzie epistolografii F. Chopina, A. Mickiewicza, J. Słowackiego i C. K. Norwida). Sztuka pisania: o liście polskim w wieku XIX / red. J. Sztachelska, E. Dąbrowicz. Białystok : Wydawnictwo Uniwersytetu w Białymstoku, 2000. S. 19-31.

6. Lubas-Bartoszyńska R. Style wypowiedzi pamiętnikaskiej. Kraków : Wydawnictwo naukowe Wyższej Szkoły Pedagogicznej, 1983. 224 s.

7. Piechota M. Dziennik. Stownik literatury polskiej XIX wieku / red. J. Bachórz, A. Kowalczykowa. Wrocław : Zakład Narodowy im. Ossolińskich, 1991. S. 202-204.

8. Sienkiewicz K. Dziennik podróży po Anglii 1820-1821. Wrocław : Zakład Narodowy im. Ossolińskich, 2007. $351 \mathrm{~s}$.

9. Sierotwiński S. Słownik terminów literackich: teoria i nauki pomocnicze literatury. Wrocław : Zakład Narodowy im. Ossolińskich, 1970. $411 \mathrm{~s}$.

10. Skwarczyńska S. Teoria listu na podstawie lwowskiego pierwodruku / oprac. E. Feliksiak, M. Leś. Białystok : Wydawnictwo Uniwersytetu w Białymstoku, 2006. $427 \mathrm{~s}$.

\section{References (translated \& transliterated)}

1. Yershov, V. (2010). Polska memuarystychna literatura Pravoberezhnoi Ukrainy doby romantyzmu [Polish memoir literature of the Right Bank Ukraine of the Romantic era]. Zhytomyr: Polissia [in Ukrainian].

2. Felińska, E. (1852). Wspomnienia z podróży do Syberji, pobytu w Berezowie i w Saratowie [Memories of the Journey to Siberia, Staying in Berezovo and Saratov] (Vol. 1). Wilno: Nakładem i drukiem J. Zawadzkiego [in Polish].

3. Felińska, E. (1852). Wspomnienia z podróży do Syberji, pobytu w Berezowie i w Saratowie [Memories of the Journey to Siberia, Staying in Berezovo and Saratov] (Vol. 2). Wilno: Nakładem i drukiem J. Zawadzkiego [in Polish].

4. Felińska, E. (1853). Wspomnienia z podróży do Syberji, pobytu w Berezowie i w Saratowie [Memories of the Journey to Siberia, Staying in Berezovo and Saratov] (Vol. 3). Wilno: Nakładem i drukiem J. Zawadzkiego [in Polish].

5. Grzesiak, D. (2000). Struktura listu romantycznego (na przykładzie epistolografii F. Chopina, A. Mickiewicza, J. Słowackiego i C. K. Norwida) [The structure of the letter of the Romantic era (on the example of the epistolary of F. Chopin, A. Mickiewicz, J. Slovacki and C. K. Norvid]. Sztuka pisania: o liście polskim w wieku XIX - The art of writing: about the Polish letter of the XIX century. J. Sztachelska \& E. Dąbrowicz (Eds.). Białystok: Wydawnictwo Uniwersytetu w Białymstoku [in Polish].

6. Lubas-Bartoszyńska, R. (1983). Style wypowiedzi pamiętnikaskiej. Kraków [Styles of memoir expression]. Kraków: Wydawnictwo naukowe Wyższej Szkoły Pedagogicznej [in Polish].

7. Piechota, M. (1991). Dziennik [Diary]. Słownik literatury polskiej XIX wieku - Dictionary of Polish literature of the XIX century. J. Bachórz \& A. Kowalczykowa (Eds.). Wrocław: Zakład Narodowy im. Ossolińskich [in Polish].

8. Sienkiewicz, K. (2007). Dziennik podróży po Anglii 1820 - 1821 [Diary of a trip to England 1820 1821]. Wrocław: Zakład Narodowy im. Ossolińskich [in Polish].

9. Sierotwiński, S. (1970). Słownik terminów literackich: teoria i nauki pomocnicze literatury [Dictionary of literary terms: theory and special literary disciplines]. Wrocław: Zakład Narodowy im. Ossolińskich [in Polish].

10. Skwarczyńska, S. (2006). Teoria listu na podstawie lwowskiego pierwodruku [Letter theory. Based on the Lviv first edition]. Białystok: Wydawnictwo Uniwersytetu w Białymstoku [in Polish].

Статтю отримано $15.09 .2020 \mathrm{p}$.

Прийнято до друку 20.10.2020 p. 